\title{
MEMBRANE TRANSPORT OF DRUG UNDER NONISOTHERMAL CONDITIONS
}

\author{
KAKUJI TOJO, Y. W. CHIEN, Y. SUN, AND M. GHANNAM \\ Department of Pharmaceutics, Controlled Drug Delivery Research Center, College of Pharmacy, \\ Rutgers University, Busch Campus, P.O. Box 789 Piscataway, NJ 08855-0789 U.S.A.
}

Key Words: Medical Chemical Engineering, Drug Delivery, Silicone Elastomer, Nonisothermal Transport, desoxycorticosterone, Testosterone

\section{Introduction}

Drug transport through a polymeric membrane under nonisothermal conditions is of great importance in gaining an understanding of the effect of environmental temperature on the rate of drug release from membrane-controlled transdermal delivery systems. Since physicochemical properties such as the diffusivity and solubility of the penetrant in the polymer may depend largely upon the system temperature, the drug concentration in the plasma after transdermal delivery may be subject to variations in the environmental temperature.

In this communication, the permeation kinetics of steroids through silicone elastomers is studied under nonisothermal conditions using a well-calibrated in vitro membrane permeation system.

\section{Experimental}

A hydrodynamically well-calibrated membrane permeation system ${ }^{11)}$ was used in this in vitro experiment. After assembling the silicone (polydimethylsiloxane) membrane $(0.013 \mathrm{~cm}$ thick) between the donor and receptor compartments, a suspension of a model drug (desoxycorticosterone or testosterone) in aqueous $40 \%$ PEG 400 solution was added into the donor compartment and the same solution with no drug was filled into the receptor compartment. The donor and receptor solutions were each agitated by a magnetic stirring bar $(2.54 \mathrm{~cm}$ long $)$, rotating at 425 r.p.m. The effect of the hydrodynamic boundary layer on the intrinsic rate of membrane permeation was previously found to be insignificant for the present drug/PEG 400 solution system. ${ }^{4,9)}$ Each compartment was individually maintained at constant temperature by two separate water circulating baths; the in vitro system was controlled under either isothermal or nonisothermal condition. The donor temperature varied from 10 to $60^{\circ} \mathrm{C}$ to simulate

\footnotetext{
Received April 13, 1987. Correspondence concerning this article should be addressed to $\mathrm{K}$. Tojo.
}

the environmental condition, while the receptor solution was maintained at constant temperature $\left(37^{\circ} \mathrm{C}\right)$.

At appropriate time intervals, an aliquot $(10 \mathrm{ml})$ of the receptor solution was withdrawn and immediately replaced with the same volume of fresh, drug-free $40 \%$ PEG 400 solution. The drug concentration was then analyzed by UV spectrophotometry from the peak absorbance at $245 \mathrm{~nm}$.

For the study of thermal diffusion (Soret effect), a drug solution of the same concentration (about $20 \%$ of the saturated concentration at $7^{\circ} \mathrm{C}$ ) was filled into the receptor and the donor compartments. The temperature of the donor solution was then varied between 7 and $60^{\circ} \mathrm{C}$, while the receptor temperature was maintained constant $\left(37^{\circ} \mathrm{C}\right)$. It was found that the temperature gradient across the membrane hardly caused drug transport under the present experimental conditions.

\section{Mathematical Model}

Since the drug transport across the membrane caused by the temperature gradient (thermal diffusion) is negligible under the present experimental conditions, the drug concentration profile in the silicone membrane is given by:

$$
\frac{\partial C}{\partial t}=\frac{\partial}{\partial x}\left(D \frac{\partial C}{\partial x}\right)
$$

where $D$ is the drug diffusivity, which is assumed to follow the Arrhenius relationship:

$$
D=D_{0} \exp \left[-\frac{E_{d}}{R T_{0}}\left(\frac{T_{0}}{T}-1\right)\right]
$$

where $D_{0}$ is the drug diffusivity at $T_{0}(=310.15 \mathrm{~K}=$ $37^{\circ} \mathrm{C}$ ), $R$ is the gas constant and $E_{d}$ is the activation energy for diffusion through the polymer matrix.

The temperature in the in vitro permeation system is assumed to change in a linear manner (Fig. 1) as follows: 
Table 1. Thermodynamic and physical properties of $40 \% \mathrm{PEG} 400$ solution and silicone membrane system

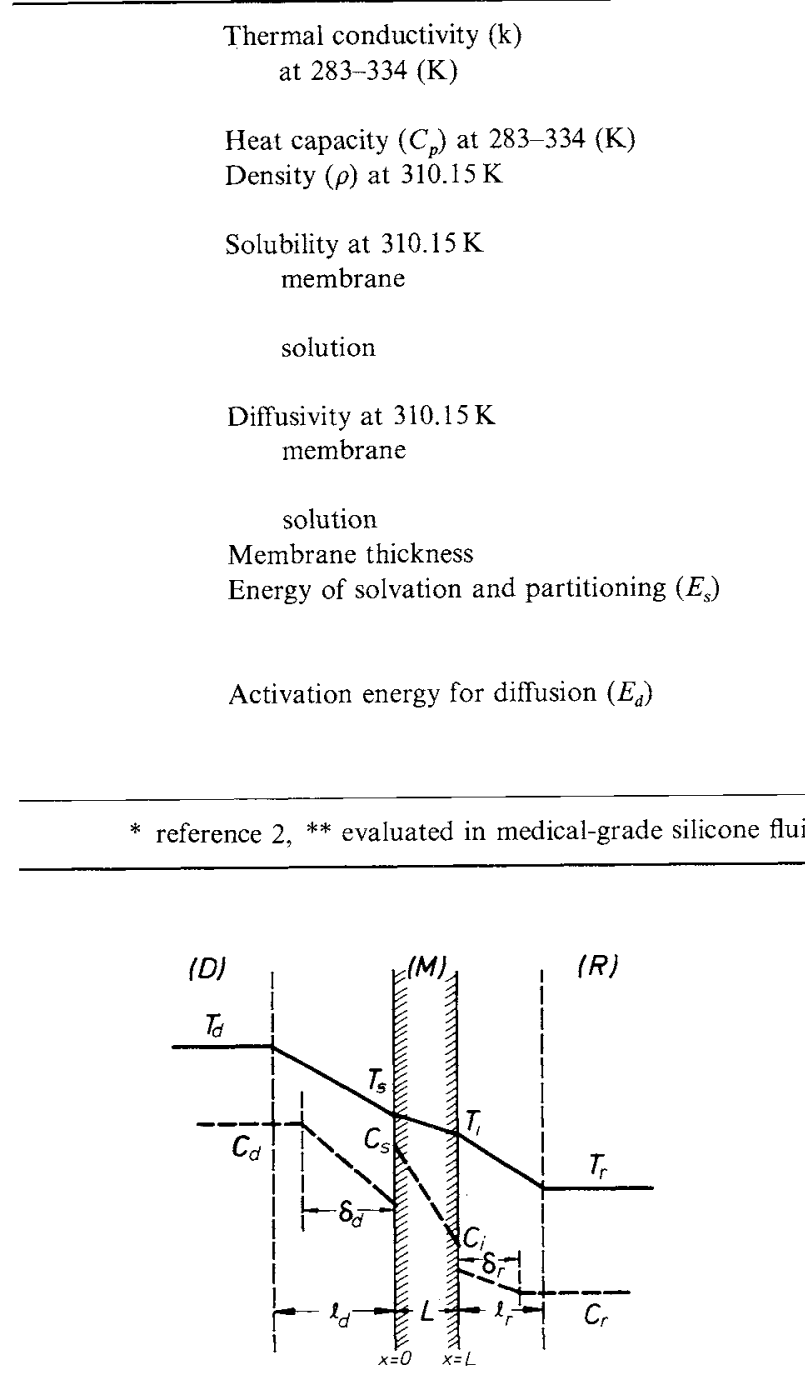

Fig. 1. Temperature and concentration profiles in a nonisothermal membrane permeation system based on the film theory.

$$
T(x)=a x+b
$$

Donor solution temperature:

$$
x<-l_{d}: \quad T=T_{d}
$$

Membrane surface temperature:

1) on the donor-side surface:

$$
x=0: \quad T=T_{s}
$$

2) on the receptor-side surface:

$$
x=L: \quad T=T_{i}
$$

Receptor solution temperature:

$$
x=L+l_{r}: \quad T=T_{r}
$$

where $l_{d}$ and $l_{r}$ are the thickness of thermal boundary layers in the donor side and the receptor side, respectively.
$0.222 \mathrm{~W} / \mathrm{m} \cdot \mathrm{K}$ (membrane) ${ }^{\dagger}$

$0.452 \mathrm{~W} / \mathrm{m} \cdot \mathrm{K}$ (solution) ${ }^{\dagger}$

$3347 \mathrm{~J} / \mathrm{kg} \cdot \mathrm{K}$ (solution) ${ }^{\dagger}$

$1120 \mathrm{~kg} / \mathrm{m}^{3}$ (membrane) ${ }^{\dagger \dagger}$

$1050 \mathrm{~kg} / \mathrm{m}^{3}$ (solution)

$0.206 \mathrm{~kg} / \mathrm{m}^{3}$ (desoxycorticosterone)

$0.156 \mathrm{~kg} / \mathrm{m}^{3}$ (testosterone) ${ }^{\sharp \sharp}$

$1.192 \mathrm{~kg} / \mathrm{m}^{3}$ (desoxycorticosterone) ${ }^{\sharp}$

$0.508 \mathrm{~kg} / \mathrm{m}^{3}$ (testosterone) ${ }^{\sharp}$

$2.9 \times 10^{-11} \mathrm{~m}^{2} / \mathrm{s}$ (desoxycorticosterone)

$2.1 \times 10^{-11} \mathrm{~m}^{2} / \mathrm{s}$ (testosterone)

$0.98 \times 10^{-10} \mathrm{~m}^{2} / \mathrm{s}^{*}$

$1.3 \times 10^{-4} \mathrm{~m}$

$3.01 \times 10^{4} \mathrm{~J} / \mathrm{mol}$ (desoxycorticosterone) ${ }^{* *}$

$3.05 \times 10^{4} \mathrm{~J} / \mathrm{mol}$ (testosterone)**

$2.38 \times 10^{4} \mathrm{~J} / \mathrm{mol}$ (desoxycorticosterone)

$3.10 \times 10^{4} \mathrm{~J} / \mathrm{mol}$ (testosterone) 
Table 2. Steady-state rate of drug permeation under various temperature conditions

\begin{tabular}{|c|c|c|c|}
\hline Drug & \multicolumn{2}{|c|}{ Temperature $\left[{ }^{\circ} \mathrm{C}\right]$} & $d Q / d t\left[\mu \mathrm{g} / \mathrm{cm}^{2} \mathrm{~h}\right]$ \\
\hline & $T_{d}$ & $T_{i}$ & \\
\hline \multirow[t]{8}{*}{ Testosterone } & 10 & 10 & 0.98 \\
\hline & 20 & 20 & 2.04 \\
\hline & 37 & 37 & 8.83 \\
\hline & 50 & 50 & 22.19 \\
\hline & 50 & 37 & 18.62 \\
\hline & 10 & 37 & 4.21 \\
\hline & 20 & 37 & 5.22 \\
\hline & 30 & 37 & 6.73 \\
\hline \multirow[t]{8}{*}{ Desoxycorticosterone } & 17 & 37 & $13.2^{*}$ \\
\hline & 27 & 37 & $17.3^{*}$ \\
\hline & 30 & 37 & 14.8 \\
\hline & 37 & 37 & 18.0 \\
\hline & 37 & 37 & $21.8 *$ \\
\hline & 47 & 37 & $25.6^{*}$ \\
\hline & 50 & 37 & 24.7 \\
\hline & 60 & 37 & 38.1 \\
\hline
\end{tabular}

* Membrane obtained from a different batch prepared under the same production conditions.

basis of the correlation equation for hydrodynamic boundary layer in the present membrane permeation system: ${ }^{11)}$

$$
N u=0.234 \operatorname{Re}^{0.57} \operatorname{Pr}^{0.33}
$$

A literature survey indicates that the exponent of the Reynolds number in the $\mathrm{Nu}-\mathrm{Re}-\mathrm{Pr}$ correlation equation depends upon the system design of heat transfer and usually ranges from $1 / 2$ to $2 / 3$ in a closed system such as an agitated tank. ${ }^{6)}$ The exponent 0.57 in Eq. (7) falls within the range established in the literature.

The thermodynamic and physical properties of $40 \%$ PEG 400 solution and silicone membrane system are listed in Table $\mathbf{1 .}$

The temperatures of the membrane surfaces, $T_{i}$ and $T_{s}$, can be determined from the following relationship:

$\left(T_{d}-T_{s}\right) k_{d} / l_{d}=\left(T_{s}-T_{i}\right) k_{m} / L=\left(T_{i}-T_{r}\right) k_{r} / l_{r}$

\section{Results and Discussion}

The steady-state rates of membrane permeation for desoxycorticosterone and testosterone under various temperature conditions are listed in Table 2. The variation in temperature of the donor solution was found to affect significantly the rate of membrane permeation of the drugs.

The experimental profiles of membrane permeation for desoxycorticosterone and testosterone are compared with those calculated from Eq. (6) in Figs. 2 and 3 , respectively. The activation energy for diffusion, $E_{d}$, and the overall energy of solvation and partitioning, $E_{s}$, were previously determined from permeation data obtained under various isothermal con-

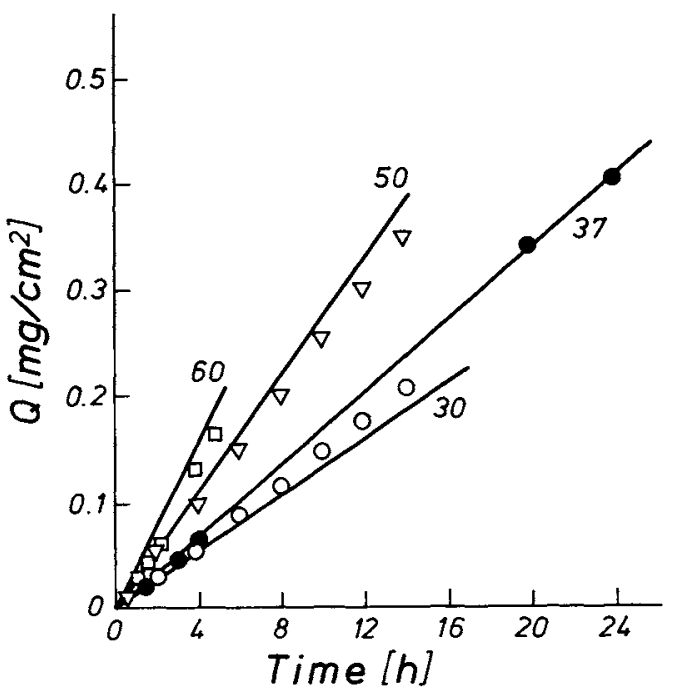

Fig. 2. Permeation profiles of desoxycorticosterone through silicone membrane. Key: $(\square, \triangle, O, 0)$ experimental; - calculated from Eq. 6 . The number with each line is the temperature of donor solution.

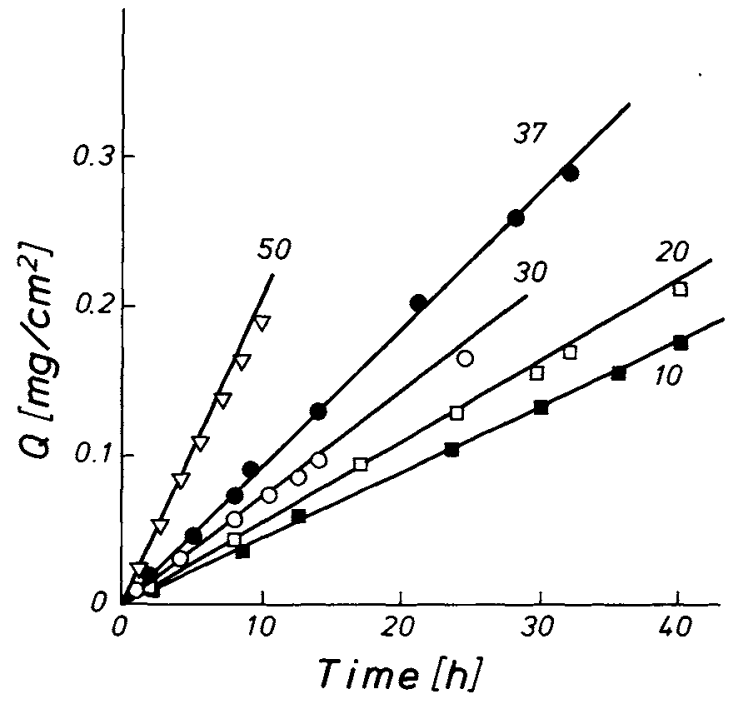

Fig. 3. Permeation profiles of testosterone through silicone membrane. Key: $(\triangle, O, O, \square, \boldsymbol{\square})$ experimental; calculated from Eq. (6). The number with each line is the temperature of donor solution.

ditions. ${ }^{4,9)}$ The diffusivity across the membrane was so determined that the calculated permeation profile under the isothermal condition at $37^{\circ} \mathrm{C}$ agreed with the experimental one. The diffusivity obtained in this experiment was found to be of the same order of magnitude as that for various steroids determined by the time-lag method. ${ }^{13)}$

The temperature of the membrane surfaces evaluated from Eq. (8) was found to be close to the average temperature between the donor and receptor solutions. This finding implies that the isothermal system can approximate to the present nonisothermal experiment for membrane permeation if the average 


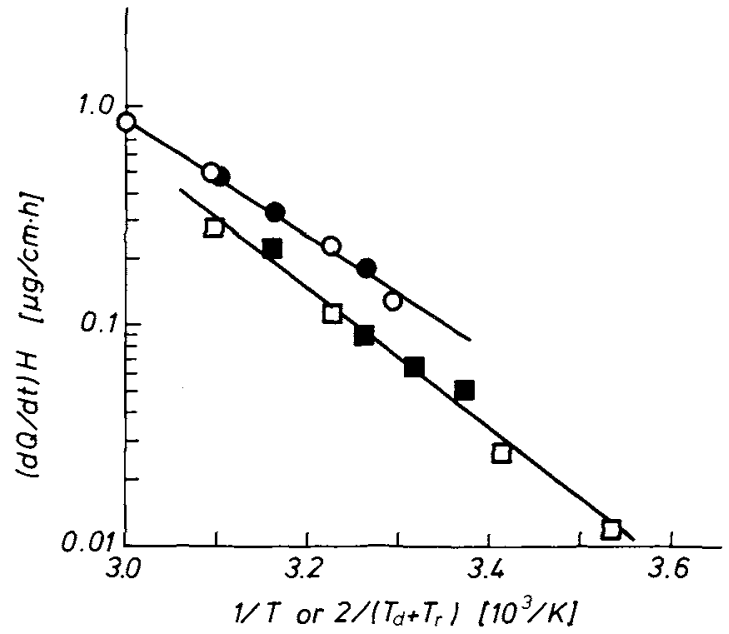

Fig. 4. The steady-state rate of permeation as a function of the reciprocal of absolute temperature (Arrhenius relationship). Key: ( $\square$ ) testosterone/isothermal; ( $\square$ ) testosterone/ nonisothermal, (O) desoxycorticosterone/isothermal; desoxycorticosterone/nonisothermal. The average value of $T_{d}$ and $T_{r}$ was used as the system temperature under nonisothermal conditions.

temperature between the donor and receptor solutions is taken into consideration as the system temperature.

Based on this logical assumption, the rates of membrane permeation for desoxycorticosterone and testosterone obtained under isothermal or nonisothermal conditions are plotted as a function of the reciprocal of the absolute temperature (Arrhenius relationship) in Fig. 4. As expected, the experimental permeation rates obtained under non-isothermal conditions fall on the same line established by the data generated under isothermal conditions.

\section{Acknowledgment}

The authors wish to thank Dow Corning, U.S.A. for the donation of silicone membranes and the establishment of Graduate Research Fellowships, of which M. Ghannam and Y. Sun are recipients.

\section{Nomenclature}

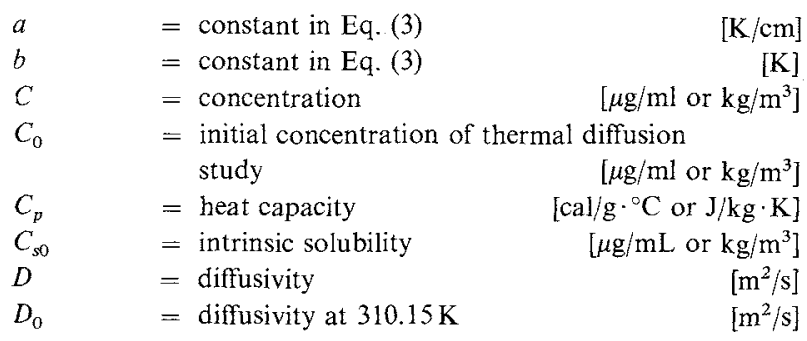

$d \quad=$ length of magnetic stirring bar $(=0.0254 \mathrm{~m}) \quad[\mathrm{m}]$

$E_{d} \quad=$ energy of diffusion $\quad[\mathrm{J} / \mathrm{mol}]$

$E_{\mathrm{s}} \quad=$ energy of solvation $\quad[\mathrm{J} / \mathrm{mol}]$

$h \quad=$ heat transfer coefficient $\quad\left[\mathrm{W} / \mathrm{m}^{2} \cdot \mathrm{K}\right]$

$k \quad=$ thermal conductivity of solution $\quad[\mathrm{W} / \mathrm{m} \cdot \mathrm{K}]$

$L \quad=$ thickness of membrane [m]

$\left.\begin{array}{ll}l_{d}= & \text { thickness of thermal diffusion layer } \\ & \text { in donor compartment }\end{array}\right]$

$l_{r} \quad=\quad$ thickness of thermal diffusion layer

$n \quad=$ rotation speed of magnetic stirring bar $\left[\mathrm{s}^{-1}\right]$

$\mathrm{Nu} \quad=$ Nusselt number $(=h d / k)$ [-]

$\operatorname{Pr} \quad=$ Prandtl number $\left(=C_{p} \mu / k\right) \quad[-]$

$Q \quad=$ cumulative amount of drug permeated

$R \quad=$ gas constant $(8.314) \quad[\mathrm{J} / \mathrm{mol} \cdot \mathrm{K}]$

$T \quad=$ temperature $\quad\left[\mathrm{K}\right.$ or $\left.{ }^{\circ} \mathrm{C}\right]$

$T_{0} \quad=$ reference temperature $\quad\left[\mathrm{K}\right.$ or $\left.{ }^{\circ} \mathrm{C}\right]$

$t=$ time

$x \quad=\begin{aligned} & \text { distance from donor-side surface of } \\ & \text { membrane }\end{aligned}$

$\delta=$ boundary layer thickness of mass transfer $\quad[\mathrm{m}]$

$\mu \quad=$ viscosity of solution $\quad[\mathrm{Pa} \cdot \mathrm{s}]$

$\rho \quad=$ density of solution $\quad\left[\mathrm{kg} / \mathrm{m}^{3}\right]$

$\langle$ Subseript〉

$$
d \quad=\text { donor compartment }
$$$$
r \quad=\text { receptor compartment }
$$

\section{Literature Cited}

1) Arkles, B.: Chemtech., September, 543 (1983).

2) Bennet, C. O. and J. E. Myers: "Momentum, Heat, and Mass Transfer," 2nd ed., McGraw Hill, New York (1974).

3) Frank-Kamenetskii, D. A.: "Diffusion and Heat Transfer in Chemical Kinetics," 2nd ed., Plenum Press, New York (1969).

4) Ghannam, M., K. Tojo and Y. W. Chien: Abstract IPT 24 and 25, p. 197, 37th APS National Meeting, Philadelphia, PA, Oct. (1984).

5) Ghannam, M., K. Tojo and Y. W. Chien: Drug Dev. \& Ind. Pharm., 12, 303 (1986).

6) Soc. of Chem. Engineers, Japan, "Kagaku Kougaku Binran," Chapt. 1, 4th ed., Maruzen, Tokyo (1978).

7) Perry, R. H. and C. H. Chilton: "Chem. Engineers' Handbook," 5th ed., McGraw Hill, New York (1973).

8) Rase, H. F.: "Chemical Reactor Design for Process Plants," Vol. 1, John Wiley \& Sons, New York (1977).

9) Sun, Y., K. Tojo and Y. W. Chien: Abstract IPT 22 and 23, p. 196, 37th APS National Meeting, Philadelphia, PA, Oct. (1984).

10) Sun, Y., K. Tojo and Y. W. Chien: Drug Dev. \& Ind. Pharm., 12, 327 (1986).

11) Tojo, K., M. Ghannam, Y. Sun and Y. W. Chien: J. Cont. Release, 1, 197 (1985).

12) Tojo, K. and L. T. Fan: Mathematical Biosciences, 57, 279 (1981).

13) Tojo, K., Y. Sun, M. Ghannam and Y. W. Chien: Drug Dev. \& Ind. Pharm., 11, 1363 (1985). 